\title{
VITAMIN D: A MODULATOR OF CELL PROLIFERATION AND DIFFERENTIATION
}

\author{
H. A. P. Pols, ${ }^{1}$ J. C. Birkenhäger, ${ }^{1}$ J. A. Foekens ${ }^{2}$ and J. P. T. M. van Leeuwen ${ }^{1}$ \\ 'Department of Internal Medicine III, Erasmus University Medical School and \\ ${ }^{2}$ The Dr Daniel den Hoed Cancer Center, Rotterdam, The Netherlands
}

\begin{abstract}
Summary - 1,25-Dihydroxyvitamin $\mathrm{D}_{3},\left[1,25(\mathrm{OH})_{2} \mathrm{D}_{3}\right]$, the biologically most active metabolite of vitamin $\mathrm{D}_{3}$, is involved in the regulation of calcium homeostasis and bone metabolism. Recently, receptors for $1,25(\mathrm{OH})_{2} \mathrm{D}_{3}$ have also been shown in cells and tissues not directly related to calcium homeostasis. Experimental data obtained with leukaemic and cancer cell lines, both in vitro and in vivo, showed the effects of $1,25(\mathrm{OH})_{2} \mathrm{D}_{3}$ on cell differentiation and proliferation. However, high doses of the sterol have to be used to observe these effects. Additional studies are needed to establish whether $1,25(\mathrm{OH})_{2} \mathrm{D}_{3}$ or suitable analogues have a therapeutic potential in malignant diseases without unacceptable toxicity like the development of hypercalcemia.
\end{abstract}

\section{INTRODUCTION}

Studies of the function and endocrinology of vitamin D over the last 80 years have elucidated its role as an important regulator of calcium and phosphate homeostasis. However, current evidence also suggest that the vitamin $\mathrm{D}$ endocrine system is involved in the modulation of a number of fundamental cellular processes not directly related to calcium homeostasis (for reviews see Refs [1-3]). In this brief review the effects of the most active metabolite of vitamin $D$, 1,25-dihydroxyvitamin $\mathrm{D}_{3}\left[1,25(\mathrm{OH})_{2} \mathrm{D}_{3}\right]$ on cell differentiation and proliferation will be discussed.

VITAMIN D:

METABOLISM AND MODE OF ACTION

The term vitamin $\mathrm{D}$ is a misnomer: cholecalciferol is not a vitamin in the generally accepted sense of an essential dietary requirement. It is synthesized photochemically in the skin and adequate amounts are produced with sufficient exposure to sunlight. It is also absorbed from the diet. $1,25(\mathrm{OH})_{2} \mathrm{D}_{3}$, is formed by two subsequent hydroxylations in the liver (25-hydroxylase) and the kidney ( $1 \alpha$-hydroxylase) and exerts its effect via a specific receptor [3]. The $1,25(\mathrm{OH})_{2} \mathrm{D}_{3}$ receptor belongs to the superfamily of steroid hormone receptors [4]. $1,25(\mathrm{OH})_{2} \mathrm{D}_{3}$ receptors are not confined to the classical target tissues, which play an important role in calcium homeo-

Proceedings of the 2nd International EORTC Symposium on "Hormonal Manipulation of Cancer: Peptides, Growth Factors and New (Anti-)Steroidal Agents", Rotterdam, The Netherlands, 9-11 April 1990. stasis but these receptors are also found in a wide variety of so-called non-classical target tissues (Table 1) [3]. In several of these target tissues $1,25(\mathrm{OH})_{2} \mathrm{D}_{3}$ undergoes an extensive side-chain oxidation at the $\mathrm{C} 24$ position [2]. This catabolism of the hormone is induced by $1,25(\mathrm{OH})_{2} \mathrm{D}_{3}$ itself and may have a dual effect: (1) directly by regulation of the cellular concentration of the hormone; and (2) indirectly by its ability to modulate the ligand-dependent up-regulation of the $1,25(\mathrm{OH})_{2} \mathrm{D}_{3}$ receptor [5].

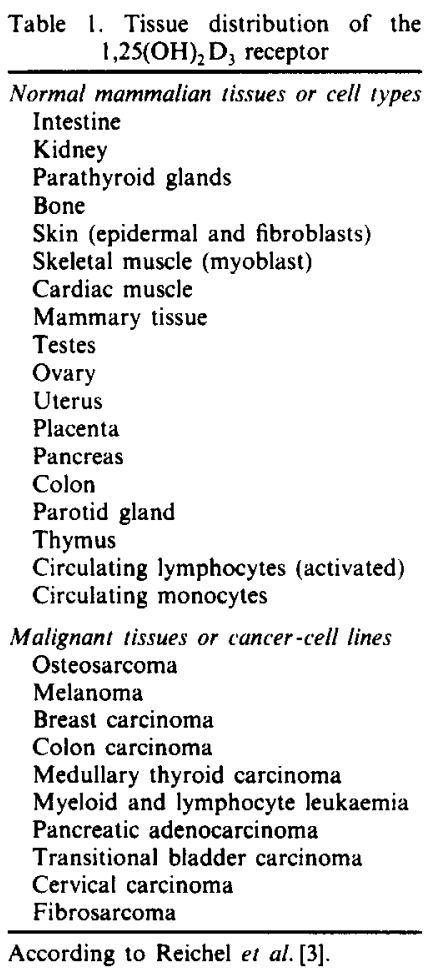




\section{EFFECTS ON CELL PROLIFERATION AND DIFFERENTIATION}

The identification of $1,25(\mathrm{OH})_{2} \mathrm{D}_{3}$ receptors in tissues not directly related to mineral homeostasis raises the question whether $1,25(\mathrm{OH})_{2} \mathrm{D}_{3}$ has other functions. In 1981 Abe et al. [6] demonstrated for the first time that $1,25(\mathrm{OH})_{2} \mathrm{D}_{3}$ induces differentiation of mouse myeloid leukaemia cells into monocytes-macrophages. This original observation was extended to other tissues and cells, especially haematopoietic and cancer cell lines [7,8]. All these studies indicated that $1,25(\mathrm{OH})_{2} \mathrm{D}_{3}$ may play a role in the regulation of cell differentiation and/or proliferation.

\section{Haematopoietic cells}

Leukaemic cell lines are frequently used models to study the effects of $1,25(\mathrm{OH})_{2} \mathrm{D}_{3}$ on haematopoietic differentiation. The overall effect of treatment of these cells with $1,25(\mathrm{OH})_{2} \mathrm{D}_{3}$ is a reduced proliferation and a preferential differentiation along the monocyte-macrophage pathway [8]. It is of interest that these alterations are preceded by modulations in the expression of oncogenes. Reitsma et al. [9] showed that $1,25(\mathrm{OH})_{2} \mathrm{D}_{3}$ reduces c-myc mRNA levels in HL-60 cells within $4 \mathrm{~h}$ of exposure to the sterol and that this change precedes the onset of other measured phenotypic changes by at least $8 \mathrm{~h}$. Other investigators showed that this inhibition of c-myc gene expression is accompanied by a decreased expression of the c-myb gene. At the same time a transient activation of the $c$-fos and a sustained expression of c-fms was observed [10]. Finally, recent evidence suggest that the action of $1,25(\mathrm{OH})_{2} \mathrm{D}_{3}$ to induce $\mathrm{Hl}-60$ cell differentiation and modulate c-myc transcription requires protein kinase $\mathrm{C}$ activity [11]. Whether the changes in expression of oncogenes are directly related to differentiation remains to be elucidated.

$1,25(\mathrm{OH})_{2} \mathrm{D}_{3}$ not only induces in vitro differentiation of leukaemic cell lines but also of normal bone marrow progenitor cells into monocyte-macrophages $[12,13]$. Furthermore, $1,25(\mathrm{OH})_{2} \mathrm{D}_{3}$ seems to be involved in the activation and also the fusion of macrophages to multinucleated giant cells [8]. With respect to mineral homeostasis it is important to emphasize that $1,25(\mathrm{OH})_{2} \mathrm{D}_{3}$ also seems to play a role in the osteoclastogenesis. Immature bone marrow cells of the monocyte-macrophage lineage are thought to be precursors of the bone-resorbing cells, the osteoclasts. In this way, $1,25(\mathrm{OH})_{2} \mathrm{D}_{3}$ may regulate skeletal homeostasis, at least in part, by modulating differentiation, fusion and activation of haematopoetic progenitors [8].

The marked effects of $1,25(\mathrm{OH})_{2} \mathrm{D}_{3}$ on growth and differentiation of leukaemic cells in vitro led Homna et al. [14] to examine whether in vivo administration of $1,25(\mathrm{OH})_{2} \mathrm{D}_{3}$ to nude mice inocculated with murine myeloid leukaemia (M1) cells would decrease leukaemogenicity. Treatment with $1,25(\mathrm{OH})_{2} \mathrm{D}_{3}$ or $1 \alpha(\mathrm{OH}) \mathrm{D}_{3}$ [rapidly converted in the liver to $1,25(\mathrm{OH})_{2} \mathrm{D}_{3}$ ] considerably prolongs the survival of the mice compared to vehicle-treated animals.

Studies in humans are scanty. Preliminary data obtained by Cunningham et al. [15] suggested antitumour activity in patients with low grade non-Hodgkin lymphomas. In contrast, treatment of patients with myelodysplastic syndrome with $2 \mu \mathrm{g} 1,25(\mathrm{OH})_{2} \mathrm{D}_{3}$ daily did not result in an apparent improvement [16]. One of the major problems for further clinical studies with $1,25(\mathrm{OH})_{2} \mathrm{D}_{3}$ is hypercalcemia, because supraphysiological doses are needed.

\section{Cancer cells}

As shown in Table $1,1,25(\mathrm{OH})_{2} \mathrm{D}_{3}$ receptors are present in a wide variety of cancer cell lines and tissues. The initial observation that $1,25(\mathrm{OH})_{2} \mathrm{D}_{3}$ inhibits cell growth in cancer cells was made in melanoma cells [17], and subsequently similar effects were observed in a still growing number of other cancer cell lines [7]. In our laboratory we have studied the effect on cell growth in the rat osteosarcoma cell UMR106. As shown in Fig. $1,1,25(\mathrm{OH})_{2} \mathrm{D}_{3}$ elicits a time-dependent decrease in the incorporation of $\left[{ }^{3} \mathrm{H}\right]$ thymidine. However, relatively high

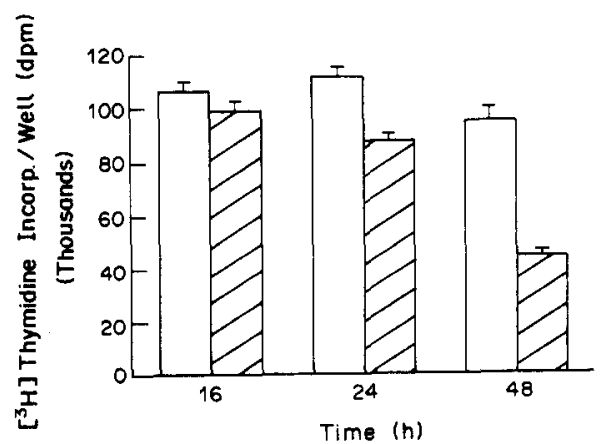

Fig. 1. UMR-106 cells were seeded at a density of 50,000 cells $/ \mathrm{cm}^{2}$ and cultured in $\alpha$ MEM with $10 \%$ FCS. After $24 \mathrm{~h}$ the medium was changed to $\alpha$ MEM with $2 \%$ charcoal-treated FCS with $(\mathbb{C})$ or without $10^{-8} \mathrm{M}$ $1,25(\mathrm{OH})_{2} \mathrm{D}_{3}(\square)$. After the times indicated $\left[{ }^{3} \mathrm{H}\right]$ thymidine incorporation was measured during the final hour of culture, as described by van der Plas et al. [30]. 

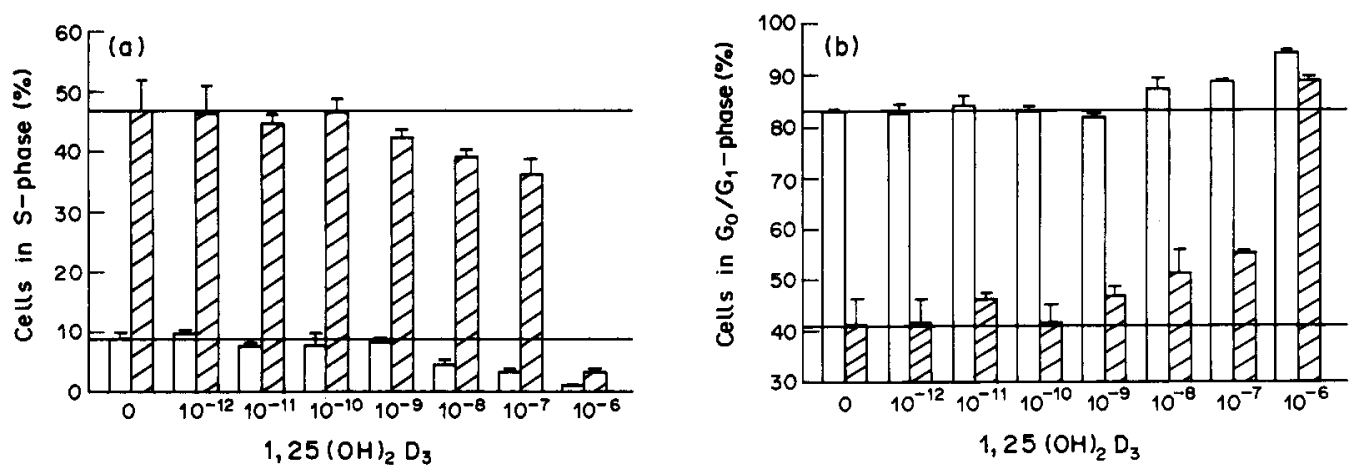

Fig. 2(a,b). MCF-7 cells were seeded at a density of 50,000 cells $/ \mathrm{cm}^{2}$ and cultured in RPMI- 1640 with $10 \%$ FCS. After $24 \mathrm{~h}$ the medium was changed to RPMI-1640 with $4.5 \%$ FCS $(\square)$ or $10 \%$ FCS ( $\square)$. At the same time vehicle or various concentrations of $1,25(\mathrm{OH})_{2} \mathrm{D}_{3}$ were added. Dual-parameter flow propidium iodide uptake in DNA was used to study the effects of $1,25(\mathrm{OH})_{2} \mathrm{D}_{3}$ on cell-cycle kinetics at $24 \mathrm{~h}$ of incubation [31].

concentrations of $1,25(\mathrm{OH})_{2} \mathrm{D}_{3}\left(>10^{-9} \mathrm{M}\right)$ are needed to obtain inhibition of cell growth. Also, in other studies comparable concentrations of $1,25(\mathrm{OH})_{2} \mathrm{D}_{3}$ had to be used to inhibit cell replication in vitro $[7,17,18]$. In some cases, inhibition of cell growth is coupled to morphological changes [18-20].

To gain more insight into the effects of $1,25(\mathrm{OH})_{2} \mathrm{D}_{3}$ on proliferation we studied its effect on cell cycle kinetics. For this purpose we used MCF-7 cells, a $1,25(\mathrm{OH})_{2} \mathrm{D}_{3}$ receptor positive human breast cancer cell line. As shown in Fig. 2(a), we observed after $24 \mathrm{~h}$ a dosedependent decrease in the number of cells in the S-phase and a concomitant increase in cell number in the $G_{0} / G_{1}$ phase of the cell cycle [Fig. 2(b)]. During these relatively short incubations no change in the number of cells in the $\mathrm{G}_{2}$ phase was observed (data not shown). Taken together these results indicate that treatment with $1,25(\mathrm{OH})_{2} \mathrm{D}_{3}$ results in an accumulation of cells in the $G_{0} / G_{1}$ phase of the cell cycle. Comparable results were obtained using the rat osteosarcoma cell line UMR-106 (data not shown). Recently, Eisman et al. [21] also showed that in T47D breast carcinoma cells $1,25(\mathrm{OH})_{2} \mathrm{D}_{3}$ inhibited progression through the $G_{0} / G_{1}$ phase. However, in contrast to our observations, they also found a transition delay in $G_{2}+M$. This may be due to differences in experimental conditions, e.g. a longer incubation time (6 days).

It is important to emphasize that for growth reduction by $1,25(\mathrm{OH})_{2} \mathrm{D}_{3}$ supraphysiological concentrations $\left(>10^{-9} \mathrm{M}\right)$ are needed. Finally, from our own data [Fig. 2(a,b)] the antiproliferative effect of $1,25(\mathrm{OH})_{2} \mathrm{D}_{3}$ in MCF-7 cells seems more potent in rapidly dividing cells cultured in $10 \%$ FCS, compared to cells cultured in $4.5 \%$ FCS which are growing more slowly [Fig. 2(a,b)]. Whether this indicates an interaction of $1,25(\mathrm{OH})_{2} \mathrm{D}_{3}$ with the response to growth factors present in the medium remains to be elucidated. However, the recent finding of a down-regulation by $1,25(\mathrm{OH})_{2} \mathrm{D}_{3}$ of epidermal growth factor receptors in T47D cells [22] at least suggests that such a mechanism could play a role.

The antiproliferative effect of $1,25(\mathrm{OH})_{2} \mathrm{D}_{3}$ has been confirmed in vivo. In high doses the sterol inhibits growth of human malignant melanoma and colonic cancer xenografts in immune suppressed mice [23] and of nitrosomethylureainduced mammary tumours in rats [24], while administration of $1 \alpha(\mathrm{OH}) \mathrm{D}_{3}$ reduced the number of lung metastases after implantation of Lewis lung carcinoma cells into mice [25]. The fact that $1,25(\mathrm{OH})_{2} \mathrm{D}_{3}$ stimulates fibronectin synthesis in several human cancer cell lines may be related to the possible antimetastatic effect of the hormone [26].

\section{CONCLUSION}

From the data currently available it seems clear that $1,25(\mathrm{OH})_{2} \mathrm{D}_{3}$ has a regulatory effect on cell growth and proliferation. However, high doses of the sterol are needed. Therefore, it remains to be established whether $1,25(\mathrm{OH})_{2} \mathrm{D}_{3}$ can produce long-term antitumour effects without unacceptable toxicity, like the development of hypercalcemia. In this light, the recent development of new vitamin $D$ analogues which have potent effects on cell proliferation and differentiation in vitro without inducing severe hypercalcemia is of interest [27-29]. 


\section{REFERENCES}

1. Manolagas S. C., Provvedini D. M. and Tsoukas C. D.: Interactions of 1,25-dihydroxyvitamin $\mathrm{D}_{3}$ and the immune system. Molec. Cell. Endocr. 43 (1985) 113-122.

2. Haussler M. R.: Vitamin D receptors: nature and function. A. Rev. Nutr. 6 (1986) 527-562.

3. Reichel H., Koeffler H. P. and Norman A. W.: The role of the vitamin D endocrine system in health and disease. N. Engl. J. Med. 320 (1989) 980-991.

4. McDonnell D. P., Mangeisdorf D. J., Pike J. W., Haussler M. R. and O'Malley B. W.: Molecular cloning of complementary DNA encoding the avian receptor for vitamin D. Science 235 (1987) 1214-1217.

5. Pols H. A. P., Birkenhäger J. C., Schilte J. P. and Visser T. J.: Evidence that the self-induced metabolism of 1,25-dihydroxyvitamin $\mathrm{D}_{3}$ limits the homologous upregulation of its receptor in rat osteosarcoma cells. Biochim. Biophys. Acta 970 (1988) 122-129.

6. Abe E., Miyaura C., Sakagami H., Takeda M., Konno K., Yamazaki T., Yoshiki S. and Suda T.: Differentiation of mouse myeloid leukemia cells induced by 1,25-dihydroxyvitamin $\mathrm{D}_{3}$, Proc. Natn. Acad. Sci. U.S.A. 78 (1981) $4990-4994$.

7. Eisman J. A.: 1,25-Dihydroxyvitamin $D_{3}$ receptor and role of $1,25(\mathrm{OH})_{2} \mathrm{D}_{3}$ in human cancer cells. In Vitamin D Metabolism: Basic and Clinical (Edited by R. Kumar). Martinus Nijhoff, The Hague (1983) pp. 365-385.

8. Suda T., Miyaura, Abe E. and Kuroki T.: Modulation of cell differentiation, immune response and tumor promotion by vitamin $\mathrm{D}$ compounds. In Bone and Mineral Research 4 (Edited by W. Peck). Elsevier. Amsterdam (1986) pp. I-49.

9. Reitsma P. H., Rothberg P. G. Astrin S. M., Trial J., Bar-Shavit Z., Hall A., Teitelbaum S. L. and Kahn A. J.: Regulation of myc gene expression in H1-60 leukemia cells by a vitamin D metabolite. Nature 306 (1983) 492-494.

10. Brevli Z. S., Christakos S. and Studzinski G. P.: Expression of monocyte-specific oncogenes c-fos and c-fms in $\mathrm{Hl}-60$ cells treated with vitamin $\mathrm{D}_{3}$ analogs correlates with inhibition of DNA synthesis and reduced calmodulin concentration. Lab. Invest. 55 (1986) $269-275$.

11. Simpson R. U., Hsu T., Wendt M. D. and Taylor J. M.: 1,25-Dihydroxyvitamin $D_{3}$ regulation of c-myc protooncogene transcription. Possible involvement of protein kinase C. J. Biol. Chem. 264 (1989) 19710-19715.

12. Miyaura C., Abe E., Nomura H., Nishii Y. and Suda T. 1 $\alpha, 25$-Dihydroxyvitamin $\mathrm{D}_{3}$ suppresses proliferation of murine granulocyte-macrophage progenitor cells (CFU-C). Biochem. Biophys. Res. Commun. 108 (1982) 1728-1733.

13. McCarthy D. M., San Miguel J. F.. Freake H. C., Green P. M., Zola H., Catovsky D. and Goldman J. M.: 1,25-Dihydroxyvitamin $D_{3}$ inhibits proliferation of human promyelocytic leukemia (HL60) cells and induces monocyte-macrophage differentiation in HL60 and normal human bone marrow cells. Leukemia Res. 7 (1983) 51-55.

14. Homna Y., Hozumi M., Abe E., Konno K., Fukushima M. Hata S. Nishii Y., DeLuca H. F, and Suda T.: $1 \alpha, 25$-Dihydroxyvitamin $D_{3}$ prolong survival time of mice inoculated with myeloid leukemia cells. Proc. Natn. Acad. Sci. U.S.A. 80 (1983) 201-204.

15. Cunningham D., Gilchrist N. L., Cowan R. A., Forrest G. J.. McArdle C. S. and Soukop M.: Alfacalcidol as a modulator of growth of low grade non-Hodgkin's lymphomas. Br. Med. J. 291 (1985) 1153-1155.

16. Koeffler H. P., Hirji K. and Itri L.: 1,25 Dihydroxyvitamin $\mathrm{D}_{3}$ : in vivo and in vitro effects on human pre- leukemic and leukemic myeloid stem cells. Cancer Treat. Rep. 69 (1985) 1399-1407.

17. Colston K., Colston M. J. and Feldman D.: $1 \alpha, 25$ Dihydroxyvitamin $\mathrm{D}_{3}$ inhibits the clonogenic growth of transformed cells via its receptor. Endocrinology 108 (1981) 1083-1086.

18. Frampton R. J., Omond S. A. and Eisman J. A. Inhibition of human cancer cell growth by 1,25 dihydroxyvitamin $\mathrm{D}_{3}$ metabolites. Cancer Res. 43 (1983) 4443-4447.

19. Dokoh S. Donaldson C. A. and Haussler M. R.: Influence of 1,25-dihydroxyvitamin $\mathrm{D}_{3}$ on cultured osteogenic sarcoma cells: correlation with the 1,25dihydroxyvitamin $\mathrm{D}_{3}$ receptor. Cancer Res. 44 (1984) 2103-2109.

20. Gross M., Bollman Kost S., Ennis B., Stumpf W. and Kumar R. Effect of 1,25-dihydroxyvitamin $D_{3}$ on mouse mammary tumor (GR) cells: evidence for receptors, cellular uptake, inhibition of growth and alteration in morphology at physiological concentrations of hormone. J. Bone Miner. Res. 1 (1986) 457-467.

21. Eisman J. A., Sutherland R. L., McMenemy M. L. Fragonas J. C., Musgrove E. A. and Pang G. Y. N.: Effects of 1,25-dihydroxyvitamin $\mathrm{D}_{3}$ on cell-cycle kinetics of T47D human breast cancer cells. J. Cell. Physiol. 138 (1989) 611-616.

22. Koga M., Eisman J. A. and Sutherland R. L.: Regulation of epidermal growth factor receptor levels by 1,25-dihydroxyvitamin $\mathrm{D}_{3}$ in human breast cancer cells. Cancer Res. 48 (1988) 2734-2739.

23. Eisman J. A., Barkla D. H. and Tutton P. J.: Suppression of in vivo growth of human cancer solid tumor xenografts by 1.25 -dihydroxyvitamin $\mathrm{D}_{3}$. Cancer Res. 47 (1987) 21--25.

24. Colston K. W., Berger U. and Coombes R. C.: Possible role for vitamin $\mathrm{D}$ in controlling breast cancer cell proliferation. Lancet (1989) 188-191.

25. Sato T., Takusagawa K., Asoo N. and Konno K. Antitumor effect of $1 \alpha, 25$-dihydroxyvitamin $\mathrm{D}_{3}$. Tohuku J. exp Med. 138 (1982) 445-446.

26. Franceschi R. T., Linson C. J., Peter C. J. and Romano P. R.: Regulation of cellular adhesion and fibronectin synthesis by $1 \alpha, 25$-dihydroxyvitamin $\mathrm{D}_{3}$.J. Biol. Chem. 262 (1987) 4165-4171.

27. Abe J., Morikawa M. and Miyammoto K.: Synthetic analogues of vitamin $D_{3}$ with an oxygen atom in the side chain skeleton: a trial of development of vitamin D compounds which exhibit potent differentiation-inducing activity without inducing hypercalcemia. FEBS Lett. 226 (1987) $58 \quad 62$.

28. Binderup L. and Bramm E.: Effects of a novel vitamin $D$ analogue MC-903 on cell proliferation and differentiation in tivo and on calcium metabolism in vivo. Biochem. Pharmac. 37 (1988) 889-895.

29. Koizumi T., Nakao Y., Ishizuka S., Oshida J., Hara N., Ikekawa $\mathrm{N}$. and Fijita $T$.: Novel vitamin $\mathrm{D}_{3}$ derivatives, 26-homo- $\Delta^{22}$-dehydro-1 $\alpha, 25(S)$-dihydroxyvitamin $\mathrm{D}_{3}$ and 26-homo- $\Delta^{22}$-dehydro-1 1 ,25( $R$ )-dihydroxyvitamin $\mathrm{D}_{3}$ : preferential activity in c-myc mRNA production and in induction of phenotypic differentiation of HL-60 cells. Archs Biochem. Biophys. 276 (1990) 310-316.

30. Plas A. van der, Feyen J. H. M. and Nijweide P. J.: Direct effect of parathyroid hormone on the proliferation of osteoblast-like cells: a possible involvement of cyclic AMP. Biochem. Biophys. Res. Commun. 129 (1985) 918-925.

31. Bontebal M.. Sieuwert A. M., Klijn J. G. M., Peters H. A.. Krijnen H. L. J. M., Sonneveld P. and Foekens J. A.: Effect of hormonal manipulation and doxorubicin administration on cell cycle kinetics of human breast cancer cells. Br. J. Cancer 60 (1989) 688-692. 